\title{
ВАЛЕОЛОГІЧНІ ОСНОВИ ДУХОВНОГО РОЗВИТКУ ОСОБИСТОСТІ
}

\author{
Ю. Д. Бойчук \\ д. пед. н., професор, проректор з наукової роботи \\ Харківського національного педагогічного університетуімені Г. С. Сковороди
}

\section{Н. В. Науменко}

к. пед. н., викладач кафедри педагогіки та психології

Національного фармацевтичного університету (м. Харків)

Здоров’я в сучасномусуспільстві розглядається як глобальна проблема, яка на рівні соціуму визначає його можливості щодо виживання, а на індивідуальному — можливості особистості щодо самоактуалізації. Особливої значущості феномену здоров'я надає його безпосередній зв'язок із духовними основами розвитку людини. Саме духовне здоров'я в умовах ціннісної кризи цивілізації стає основним чинником відновлення гармонійних стосунків людини з собою, суспільством та природою і вирішення глобальних проблем сучасності. Оскільки цінності духовного здоров'я формуються в процесі виховання особистості, найвагомішу роль у цьому процесі відіграє система освіти [3, с. 5; 4, с. 16].

Із огляду на соціально-економічні негаразди в нашому суспільстві, масове поширення шкідливих звичок, пропаганду моральної розбещеності, агресії та жорсткості, реальна освітня практика поки ще не забезпечує збереження і поліпшення стану духовного здоров'я особистості.

Завдання формування духовності в контексті проблематики становлення духовно здорової особистості як одного з пріоритетних завдань реформування і модернізації вітчизняної освіти передбачено певними концептуальними й директивними документами. Його виконання потребує поглибленого аналізу духовного здоров'я, чинників формування, взаємозв'язку з іншими соціальними і освітніми феноменами. Відтак духовне здоров'я стає важливим об'єктом освітнього аналізу в контексті впровадження в освітній процес духовно-орієнтованих цілей сучасної освіти загалом та ідей здоров'язбереження зокрема.

Продуктивні ідеї щодо духовного здоров’я простежуються ще у творах Платона, Протагора, Аристотеля, Аврелія Августина, Хоми Аквінського, Р. Декарта, Дж. Локка, І. Канта, Г. Гегеля. У сучасних умовах характеристика людини як духовно здорової особистості та духовної та соціальної істоти в контексті ії природи досліджується на міждисциплінарній основі та $є$ предметом аналізу філософів, культурологів, педагогів, психологів, соціологів та інших науковців. Найбільш досліджуваним $є$ перетин проблематики духовного здоров'я та формування духовної культури в освітньому процесі, де духовна культура розглядається як зміст і мета освітньої діяльності, а духовне здоров'я — як складова духовної культури особистості (В. Андрущенко, І. Бех, А. Богуш, М. Боришевський, І. Бужина, Л. Васильченко, Т. Воронцова, М. Гончаренко, І. Зайченко, О. Зеліченко, І. Зязюн, І. Срмаков, Н. Іордакі, Н. Карленко, С. Кримський, Ж. Маценко, С. Помиткін, С. П’янзін, О. Савченко, І. Степаненко, О. Сухомлинська, В. Сухомлинський, М. Тесленко, В. Франкл, Г. Шевченко, Е. Фромм, Ж. Юзвак, К. Юнг та ін.).

В усіх державних освітянських документах від дошкілля до вищої школи в Україні передбачена кінцева мета виховання духовності - розвиток духовних цінностей і формування свідомої особистості. Натомість наразі ще не визначено однозначно сутність понять «духовність», «духовний розвиток», «духовне здоров'я», «мораль», «моральність». Подекуди в педагогічній практиці ці поняття ототожнюють між собою. Однак це зовсім різні поняття за своєю сутністю, хоча й мають спільні універсальні загальнолюдські цінності, як-от: Істина, Краса, Добро.

Аналіз наукових досліджень (А. Богуш, М. Боришевський, О. Вишневський, М. Каган, С. Кримський, I. Степаненко, В. Сухомлинський, С. Франкл, Г. Шевченко, Ж. Юзвак, К. Юнг та ін.) дозволив визначити їх спільні ознаки та специфіку кожного з них. Установлено, що поняття «духовність» та похідні від нього, хоча і відображають єдину реальність, мають мінливий історичний зміст у контексті відмінностей культури. Відповідно і поняття «духовне здоров'я» може інтерпретуватися в досить широкому діапазоні характеристик. На сьогодні найбільш актуальні дослідження духовного світу людини безпосередньо пов'язані з проблематикою духовного здоров'я, оскільки першочерговими $є$ завдання подолання духовної кризи сучасної цивілізації. Духовне здоров'я в контексті функціонування різноманітних форм духовного життя в соціумі досліджується передусім як соціальна обумовленість духовної діяльності та суспільної свідомості.

Духовне здоров'я, як і будь-яке інше поняття, поліаспектне у своїй змістовій характеристиці. Розуміння сутності духовного здоров'я дозволяє забезпечити адекватне розуміння «цілісності» як фундаментального поняття особистості та її духовного світу і є інтегрованою характеристикою як суб'єкта освітньої діяльності, уміщуючи в собі інтелектуальний, морально-етичний, емоційно-вольовий та естетичний аспекти. Гармонійна єдність цих аспектів характеризує емоційно-чуттєве, позитивне ставлення суб'єкта до світу, мистецтва, оточуючих людей, природи, самого себе. Духовне здоров'я індивіда залежить від складників духовної культури 
людства - освіти, науки, мистецтва, релігії, моралі, етики. Тому його рівень визначатиметься особистісною потребою у засвоєнні системи цінностей та якістю мотиваційно-ціннісного ставлення до складників духовної спадщини суспільства. Духовне здоров’я $є$ інтегральним утворенням і синтезує не лише психічні чи душевні якості, а всі особистісні характеристики, оскільки його носієм є особистість, а не психіка, інтелект чи свідомість. У зв'язку з цим духовне здоров'я не може бути однозначно інтерпретоване через певні ознаки та характеристики, а являє собою постійно змінну та багатовимірну реальність буття людини з урахуванням як внутрішніх духовних чинників ії поведінки, так і соціокультурного контексту життєдіяльності [5, с. 18].

Духовне здоров'я забезпечує реалізацію в особистісному бутті сутнісних потенцій духовного світу людини і не дає можливості виявитися його деструктивним якостям. Воно складає основу оцінки якості духовної складової людини та їі життєдіяльності. Саме духовно здорова людина може трансформувати себе із царини «буттєвих можливостей» в реальну життєдіяльність, у межах якої здійснюється ії саморозвиток та самоактуалізація, ознакою чого є визначення смисложиттєвих орієнтирів людини.

Забезпечення духовного здоров'я особистості та формування іiі здатності до самоактуалізації мають багато точок перетину в освітній діяльності. Передусім йдеться про формування в особистості комплексу якостей і здатностей, які, будучи спрямовані на їі саморозвиток, одночасно є механізмами забезпечення духовного здоров'я. Серед таких якостей, насамперед, слід виділити: розвиток потреби та здатності особистості до усвідомленого самопізнання; спрямованість на самоідентифікацію; діяльність щодо саморозвитку й розкриття власних здібностей: формування мотивації до особистісної саморегуляції; забезпечення освітніми впливами здатності особистості до саморозвитку та самоактуалізації упродовж усього життя [7, с. 22].

Проблема людини та іiї здоров'я - одвічна проблема, стрижнем якої є шлях до вільного гармонійного розвитку особистості. Бути здоровим і якомога рідше хворіти — природне бажання та прагнення людини, iі неусвідомлена потреба. Здоров'я - основа всіх наших справ, трудових і творчих звершень, сподівань, надій на майбутнє. Тому в усі часи здоров'я було і залишається основною сутністю людського існування.

Науковий аналіз глобальної еколого-демографічної ситуації, що склалася на початку нового тисячоліття, примусив замислитися кожного, хто дбає про власне життя і здоров'я, про долю своїх нащадків, майбутнє людства. Нинішня ситуація порушує питання про необхідність зміни наших уявлень, вимог щодо здоров'я людини, нації, суспільства. Для України ситуація ускладнюється ще й тим, що водночас з екологічною кризою країна перебуває в економічно-політичній кризі. Через це спостерігається прогресуюча деградація здоров'я населення, особливо дітей та шкільної молоді [6, с. 24].

Ситуація зі станом здоров'я населення в Україні погіршується ще й низьким рівнем знань переважної більшості людей щодо фундаментальних законів раціонального формування, збереження та зміцнення свого власного здоров'я впродовж усього життя, у зневажливому й нерідко безвідповідальному ставленні до цієї єдиної онтологічної цінності, якою природа нагороджує людину разом із життям.

Єдиним способом розв’язання проблеми $є$ кардинальна зміна поглядів людини на причини та наслідки нездоров'я. А досягти цього можна лише шляхом перебудови системи освіти та виховання людини, набуття знань, що дозволяють їй здійснювати гармонійний розвиток згідно з вимогами сьогодення.

Поняття «здоров'я» досить складне і характеризує результат взаємодії індивіда з оточуючим середовищем - умови існування, провідні мотиви його життєдіяльності та світобачення. Поняття здоров'я має широкий інтегральний зміст, для розкриття якого потрібні знання з різних галузей людинознавства.

Від того, з яких філософських позицій воно розглядається, залежить, яким аспектам надається перевага. У зв'язку з цим передбачається вивчення здоров'я як цілісного багатовимірного феномена. Щоб бути здоровим, недостатньо мати тільки здорове тіло. Адже, якщо людина не живе духовним життям, iї фізичні резерви швидко вичерпуються, що неминуче призведе до хвороби. Якщо людина перебуває тривалий час в атмосфері страху, психоемоційного напруження (стресу), це може призвести до онкологічних, серцево-судинних чи психічних захворювань. I навпаки, в історії людства відомі випадки, коли завдяки великій духовності та вірі люди з надзвичайно важкими захворюваннями чи травмами не тільки одужували, але й поверталися до активного життя.

3 огляду на те, що феномен людини становить собою діалектичну єдність матеріального і духовного, біологічного і соціального, особистого і суспільного, виникає необхідність розглянути духовну складову здоров'я людини [5, с. 19].

Як і будь-яку фундаментальну якість, духовний розвиток однозначно й стисло визначити не можна. Духовність для віруючої людини - це ії здатність відчувати себе відповідальною за власні дії перед Богом. Люди, які не вірять у реальність Бога, але визнають існування такого собі Космічного Розуму, Свідомості Всесвіту, Сил Природи, Совісті сприймають духовність як синонім моральності. Не можна заперечити наявність діалектичного взаємозв' язку між поняттями «моральність» і «духовність», однак їх не слід ототожнювати.

Духовний розвиток це найефективніший шлях, який може видалити причини всіх проблем людини. Саме бездуховність і неосвіченість є головними причинами абсолютно всіх негаразд і хвороб людини. Духовність 
слід розуміти як діяльність свідомості, спрямовану на пошук сенсу життя та свого місця в ньому, визначення критеріїв добра і зла, оцінювання за ними людей і подій, формування мотивів поведінки згідно із загальнолюдськими принципами моральності або всупереч їм. Духовні цінності відіграють роль повсякденних орієнтирів у предметній і соціальній дійсності та визначають поведінку людини [11, с. 32].

Усе більше й більше людей говорять про значення духовних надбань. Духовні уподобання повинні починатися в родині. Вони мають дозволяти людям обумовлювати свої рішення, відносини й роботу, забезпечувати соціальний, економічний і духовний добробут людей. Права людини та загальні етичні цінності охороняють нас від повторення трагедій минулого й надають нам бачення майбутнього світу, у якому права людини та етнічні норми світової духовної культури стануть неписаними законами й будуть виконуватися природно, як спосіб життя.

Тривалий час духовність прирівнювали до релігійності. Особливо це було виражено в радянський період. У той час, коли церква була відокремлена від держави, тема духовності була викреслена з наукових робіт, але сьогодні вона знову ввійшла до кола сучасних досліджуваних проблем.

Досліджуючи наукову літературу, спостерігаємо, що поняття «духовне» та «душевне» (або «психічне») нерідко ототожнюються. Разом із тим, говорячи про взаємозв'язок між здоров'ям людини та їі духовним світом, дуже важко провести чітку межу між душевним (психічним) і духовним, які в конкретній людині є нічим іншим, як абстрактними аспектами єдиного цілого. У тих випадках, коли людина перебуває в стані суперечності між своєю душею і духом, що трапляється, наприклад, у ситуації вибору між неспокоєм і напруженням духовних пошуків та душевним благополуччям і рівновагою, виділення цих аспектів із метою «розібратися в собі» є просто необхідним. Складовими духовного світу людини виступають знання, моральні, художньоестетичні, життєво-практичні переживання, ціннісні орієнтації та установки. Свої життєві проблеми, у тому числі стан свого здоров'я, людина сприймає крізь призму певних понять, образів, почуттів, уявлень, смислів та інших духовних утворень. Світогляд кожної конкретної людини є неповторним, і тому практичні підходи людей до розв’язання проблеми здоров'я дуже різняться між собою [12, с. 29-30].

Отже, досвід освоєння людиною навколишньої та своєї внутрішньої реальності концентрується у відповідних соціальних формах духовності: релігії, філософії, науці, моралі тощо. Так, у релігії людина спонукається до здорового способу життя вірою в божі заповіді, якими встановлюється культ тілесної та духовної чистоти. У філософії та науці — веліннями розуму, в етиці — моральними настановами, у мистецтві - почуттям прекрасного.

Філософським осмисленням духовності займалися І. Бех, М. Гончаренко, М. Кисельов, С. Кримський, В. Кулініченко, І. Степаненко та інші дослідники. Вони розглядають «духовність» із двох позицій: ототожнюють «духовність» із духовною культурою, як поведінковий аспект, тобто поведінку людини в соціумі, яку вона буде засвоювати упродовж свого життя, через освоєння духовного змісту культури - це і буде її другим духовним народженням. 3 іншого боку, розглядають духовність як внутрішню якість особистості, одним із чинників свідомої людини, як їі духовні цінності [2, с. 19].

Філософський словник визначає духовність як спосіб життєдіяльності, специфіка якого полягає у пріоритетному задоволенні потреби у пізнанні - світу, себе i, головне, смислу та призначення свого життя.

С. Кримський вважав, що духовність — «...це здатність переводити універсум зовнішнього буття у внутрішній всесвіт особистості на етичних засадах, здатність створювати той внутрішній світ, завдяки якому реалізується собітотожність людини, його воля відносно жорсткої залежності перед ситуаціями, які постійно змінюються. Духовність призводить до свого роду сенсової космогонії, поєднання образу світу з моральним законом особистості...» [7, с. 24].

Н.Силуянова вважає, що духовність позначає якісну відмінність психічної діяльності людини від психічної активності тварин. Вона пропонує розрізняти терміни «дух», «духовний», «духовність». Ця необхідність обумовлена тим, що жодне інше поняття — ні свідомість, ні розум, ні мислення, ні інтелект — не фіксують дану реальність у всій їі цілісності. Дослідниця поділяє духовність на релігійну і моральну. Моральна духовність зорієнтована на реалізацію зазначеної потреби безпосередньо на практиці людських взаємовідносин, взаємних зобов'язань людей один перед одним [14, с. 101].

Отже, духовність із позиції філософів є ціннісним виміром буття внутрішнього та зовнішнього в їх єдності, у співвіднесенні з Вічністю, з вічним Абсолютом, а не з повсякденністю, з устремлінням до Істини, Добра, Краси, із творчістю й свободою.

Інша позиція в трактуванні духовності у психологів, які вважають, що вона не інтелектуальність, не ідеалізм, не чиста мораль, не релігійність і не емоційність. Водночас усе це в сукупності становить Велику цінність, підготовку до самодисципліни, саморозвитку й очищення себе від усякого зла. Вони розуміють ії як творчу здатність особистості до самореалізації та самовдосконалення, що зумовлюється такими особливостями когнітивно-інтелектуальної, чуттєво-емоційної та вольової сфер, які є необхідними для успішного формування та реалізації потреби в цілеспрямованому пізнанні й ствердженні в ії життєдіяльності істини, загальнолюдських етичних і есте- 
тичних цінностей, усвідомленні єдності себе і Всесвіту. На думку психологів, духовність є інтегрованою якістю особистості, ієрархією метамотивів і потреб, виходячи з яких особистість оцінює себе, інших, довкілля, а найсуттєвішими для духовного розвитку особистості є такі потреби: самоповага, пізнання світу, себе, сенс життя, сприймання й створення краси, здійснення добра та справедливості, досягнення психічної досконалості.

Так, Ж. Юзвак розуміє духовність як складне поєднання таких особливостей інтелектуальної, чуттєвоемоційної та вольової сфер людської психіки, які сприяють формуванню потреби в пізнанні світу, себе, оточуючих людей і засвоювання духовних цінностей. Психолог розглядає духовність як здатність людини до психічного та особистого вдосконалення та самовдосконалення [15, с. 376].

I. Бех під духовністю розуміє, перш за все, зосередженість на моральній культурі людства. «Адже духовність, - наголошує вчений, — так чи інакше передбачає вихід за межі егоїстичних інтересів, особистої користі й зосередженість на моральній культурі людства. То й цілі і наміри духовно зрілої особистості вкорінені в системі надіндивідуальних цінностей, завдяки чому вони виконують функцію вищого критерію орієнтування у світі й опори для особистісного самовизначення» [1, с. 123].

Дещо інше розуміння духовності педагогами. Під духовно вихованою людиною В. Сухомлинський розумів високоморальну, гуманістично спрямовану, фізично досконалу й естетично розвинену особистість, віддану своєму народу, своїй Батьківщині, яка не є байдужою до горя й біди інших людей, яка співчуває іншому і в разі потреби надає дієву допомогу.

Духовність це поняття, що узагальнено відображає цінності (смисли) і відповідний їм досвід, протилежний емпіричному («матеріальному», «природному») існуванню людини, або, принаймні, що відрізняється від нього. Духовність виявляється у спрямуванні людини до вищих цінностей, до ідеалу, в усвідомленому спрямуванні людини до досконалості; відповідно одухотворення полягає в засвоєнні вищих цінностей, у наближенні до ідеалу.

Р. Лішиць вважає, що духовність $€$ найвищим щаблем в ієрархії цінностей, тобто належить до абсолютних, вищих цінностей. Характеризуючи духовність, дослідник наголошує на тому, що це обумовлена світоглядом і вірою спрямованість людини до Бога й до богоугідно трактованих ідеалів нижчих рівнів ієрархії цінностей, що стосуються естетичного, морального, національного, громадянського, родинного, особистісного життя людини [9, с. 12].

Духовність, на думку Р. Лівшиця, це внутрішня енергетична сила особистості, основа ії життя, ієрархія загальнолюдських, національних цінностей, творчість за законами Краси. Духовність розглядається як проблема оволодіння сенсожиттєвими цінностями, цілями та смислами. Духовність становить смисложиттєву позицію особистості у світі, у якій людина відкриває себе світові, а також іншій людині як єдиному носію родової людської сутності. Духовність виражена в прагненні до соціально-позитивних, гуманістичних цінностей, у ній відбувається розвиток родової сутності людини [9, с. 14-15].

Н. Лавриченко робить спробу поєднати поняття «духовність» $\mathrm{i}$ «моральність» у сучасній педагогічній науці, де духовність є способом індивідуального світопізнання та світовідношення в складному поєднанні з механізмом саморефлексії, тобто визначає ставлення людини до самої себе, тоді як моральність грунтується на історичному досвіді й формує такі культурні концепти, як моральні норми, принципи, поняття добра [8, с. 9].

На думку А. Богуш, духовність $є$ своєрідним інтелектуально-чуттєвим, емоційним станом особистості, що протікає на позитивному тлі поведінки й діяльності людини та характеризує їі цілісність як особистості [2, с. 19].

Отже, з педагогічного погляду, духовність - це певний тип ставлення людини до природи, суспільства, інших людей, до самої себе; індивідуальна вираженість людини в системі ії мотивів життєдіяльності; потреба в пізнанні світу, себе, смислу й призначення свого життя, потреба діяти для інших. Духовність не ототожнюється з духовним життям суспільства. Вона виступає як спосіб розвитку особистості. Якщо світогляд передбачає вибір способу життя, то духовність пов'язана з вибором свого власного образу, своєї долі та ролі, одним словом, із зустрічі з самим собою.

3 наведеного можна зробити висновок, що під духовністю розуміють процес, за допомогою якого духовний потенціал душі розвивається урівноважено та гармонійно. Духовне перетворення особистості — це процес виховання та навчання, які приводять до духовного росту. Духовне зростання є основою етики та моралі людини, iї гуманістичного розвитку. Усе, що сприяє духовному зростанню, спрямоване на добро. Якщо не керувати нашими природними потребами та бажаннями, вони можуть збити людину з духовного шляху.

Рівень духовності, на якому ми знаходимось, отримує своє відображення в наших взаєминах з навколишнім світом і самим собою. Він проявляється в моделях довільних відповідей. Тому одним із головних інструментів духовного росту є постійний контроль, розуміння наших відповідей, нашої поведінки. Людина, оволодіваючи вмінням аналізу своїх довільних відповідей, вчиться культурі мислення, розуміти свої почуття, осмислювати порядність й емоційну цілісність, проявляти в потрібний момент волю, рішучу дію, якщо вона морально виправдана [12, с. 30].

Духовність або духовний світ людини успішніше формується на основі здорового організму. Здоров'я тіла забезпечує людині не лише високу працездатність, творче довголіття, але й помітно впливає на ііі інтереси, погляди, спосіб мислення. Воно слугує джерелом духовної бадьорості, оптимізму, упевненості в собі та своїх 
творчих можливостях, пробуджує інтерес до нових духовних цінностей, стає важливою умовою культурного розвитку людини. 3 іншого боку, духовне в людині здійснює зворотний вплив на їі фізичний стан і може стати джерелом прагнення до здорового способу життя. Духовні цінності, ідеї та знання нерідко стають тією спонукальною силою, яка докорінно змінює спосіб життя людини. Здоровий спосіб життя органічно входить у сферу прекрасного, набуваючи, крім практичної, естетичну цінність.

Людина, яка піклується лише про здоров’я свого тіла й забуває про «здоров’ я духу», ігноруючи прийняті в суспільстві моральні норми й цінності, іде шляхом тваринних інстинктів. Отже, можна сказати, що неможливо досягнути духовного здоров'я без підтримання тілесного здоров'я, і навпаки. Порушення людиною гармонії між фізичним і духовним негативно впливає на обидві сфери ії життя.

Люди тягнуться до тих, хто випромінює доброту, любов, світло, тепло, позитивну енергію. Лікарі стверджують, що добрі, веселі, енергійні люди довше живуть і менше хворіють. Спокій, урівноваженість, чуйність, доброта, порядність, ввічливість характеризують здорову людину. 3 нею легко жити, приємно спілкуватися. Такі люди вміють жити в гармонії, у злагоді з самим собою, з іншими людьми. Вони веселі та щасливі, успішно розв' язують свої проблеми. Емоційно врівноважені люди сповнені щастя й любові, а головне - духовного здоров'я, яке має таке велике значення для повноцінного життя людини. Духовна складова людини є не тільки основою її здоров’я, але й основою благополуччя тих, хто її оточує.

У кожної людини свій темп розвитку та своя стадія духовного вдосконалення залежно від рівня розвитку душі та від якості способу життя, індикатором яких є здоров'я людини. Бездуховну людину не можна визнати здоровою. Установлено, що в сучасних уявленнях про здоров'я людини як цілісний багатовимірний феномен виділяють чотири його складові, а саме: фізичне, психічне, соціальне та духовне здоров'я.

Аналіз широкого спектра дефініцій дозволив нам запропонувати визначення одного 3 ключових понять «духовне здоров 'я» як складної інтегрованої особистісної якості, формування якої зумовлює готовність і спроможність особистості до всебічної реалізації себе в суспільному житті, іiі прагнення до оволодіння загальнолюдськими цінностями, спроможність до взаємодії з мікро-, мезо- та макросередовищем, здатність відчувати себе часткою навколишнього світу, бажання поліпшувати його, уміти співчувати, співпереживати, надавати допомогу іншим, будувати гармонійні взаємини з людьми, відповідально ставитися до себе та свого життя [11, с. 116].

Бездуховність починається за відсутності почуття вдячності за такі життєво важливі умови, як чисте повітря для дихання, чиста джерельна вода, сонячне тепло і світло, місце на Землі, дари ланів, лісів, луків та інші безцінні подарунки природи, які приймаються як щось само собою зрозуміле.

Сьогодні вже з'явилися праці вчених, де компетентно й докладно розглядаються шляхи реального захисту здоров’я людини та природи в кризовій ситуації. Головне - це вдосконалення духовної сфери людини, зміна її ставлення до Природи як невід’ємної частини живої системи Всесвіту. Саме в цьому, на думку багатьох учених, полягає нова етико-екологічна парадигма суспільного розвитку. Власне, обмежуючи свої меркантильні потреби й піднімаючись на вищі духовні сходинки, людство може розраховувати на вихід із кризи та порятунок від морально-екологічної катастрофи. Жадоба грошей і влади шкодить довкіллю і, найголовніше, унеможливлює духовний розвиток людини.

Духовне здоров’я людини формується багатьма чинниками. Традиційними є вплив батьків, їхній світогляд, переконання, культура, традиції, побут. Не останню роль відіграє національна внутрішня політика держави. У галузі освіти вона спрямована на забезпечення комплексного формування здоров’ я. Це положення відображається в низці державних нормативних документів і покладено в основу формування здорової особистості з високим рівнем громадянської відповідальності, готової до самостійного вибору власного місця в житті.

Державна політика реалізується через освітні заклади: дошкільні, шкільні, позашкільні, вищі навчальні заклади різних рівнів акредитації. На жаль, стратегії держави з цього питання ще не вироблено, як і наступництва, взаємодії, координації дій. Але вільне місце довго вакантним не буває. Його заповнює примітивна, розважальна, неукраїнська ерзацкультура. Юне покоління росте на прикладах віртуальних героїв мультфільмів, непереможних фантастичних людей-мишей, голівудських поліцейських суперменів.

Духовне здоров'я формується шляхом виховання в особистості позитивного спілкування, запобігання конфліктам, акцентуючи увагу на моральній вихованості як одній з важливих характеристик людини й суспільства. Духовне виховання та здоров’я повинно базуватися на природних реальних явищах, спілкуванні з довкіллям, дослідженням його з усіх сторін. Якщо держава зможе обмежити вплив на дітей електронних засобів масової інформації, то багато проблем у формуванні духовного здоров’я людини буде вирішено без особливих зусиль [10 с. $117 ; 13$, с. 6-7].

Загальна освіта повинна стимулювати бажання духовного розвитку, духовного вдосконалення, виникнення внутрішньої потреби використовувати в житті загальнолюдські моральні принципи, щоб людина розуміла, що духовне - це головне в житті, що без духовності неможливо стати по-справжньому культурною людиною. 
Недоліки освіти в цілому пов'язані з методологією загальної освіти, яка не повинна зводитися лише до розвитку мислення особистості, до набуття нею навичок аналізу, до повідомлення їй відомостей, які доречні тільки на практиці, до суми деяких уявлень про устрій навколишнього світу, вивчення фактів з історії людства, знайомства з літературою та мистецтвом, підготовки до подальшого продовження освіти. Загальна освіта повинна також дати елементарні відомості про суть людського мислення, сутність людського знання та про способи спілкування між людьми, які завжди в тому чи іншому сенсі базуються на деяких догмах або аксіомах.

\section{Література}

1. Бех І. Д. Виховання особистості : навч.-метод. посіб. / Кн. 1: Особистісно орієнтований підхід: теоретико-технологічні засади. К. : Либідь, 2003. 278 с.

2. Богуш А. М. Дефініції «духовність» $\mathrm{i}$ «моральність» в аспекті національного виховання в Україні // Морально-духовний розвиток особистості в сучасних умовах: зб. наук. пр. К., 2000. Кн. 1. С. 18-23.

3. Бойчук Ю. Д. Сучасні підходи до розуміння сутності здоров'я людини та суміжних з ним понять // Загальна теорія здоров'я і здоров'язбереження: колективна монографія за заг. ред. проф. Ю. Д. Бойчука. Харків : Вид. Рожко С. Г., 2017. С. 5-16.

4. Бойчук Ю. Д., Науменко Н. В. Духовне здоров'я: науковий аналіз поняття // Там само. С. 16-26.

5. Бойчук Ю. Д., Науменко Н. В. та ін. Підготовка майбутніх учителів до формування духовного здоров'я молодших школярів : монографія. Харків : ФОП Мезівна В. В., 2018. 128 с.

6. Гончаренко М. С. Валеопедагогические аспекты духовности : учеб. пособ. Харьков : ХНУ им. В. Н. Каразина, 2007. 400 c.

7. Крымский С. Б. Контуры духовности: новые контексты идентификации // Вопросы философии. 1992. № 12. С. 21-28.

8. Л Лавриченко Н. Категорії «соціальність», «духовність» і «моральність» в сучасній педагогічній науці // Шлях освіти. 2003. № 1. C. 7-11.

9. Лившиц Р. Л. Духовность и бездуховность личности: социально-философский анализ : автореф. дисс. ... на соиск. науч. степени д-ра фил. наук: спец. 09.00.11. Екатеринбург, 1997. 48 с.

10. Науменко Н. В. Дефінітивна характеристика поняття «духовне здоров'я людини» // Теорія та методика навчання та виховання: зб. наук. пр. Харків : ХНПУ ім. Г. С. Сковороди, 2012. Вип. 32. С. 115-124.

11. Науменко Н. В. Формування духовного здоров'я особистості як сучасна педагогічна проблема // Наукові записки. Сер. Психолого-педагогічні науки : наук.-метод. зб. Ніжин : НДУ ім. М. Гоголя, 2012. № 2. С. 32-36.

12. Науменко Н. В. Формування духовності як запорука збереження і зміцнення духовного здоров'я // Науковий часопис НПУ імені М. П. Драгоманова. Серія 16. Творча особистість учителя: проблеми теорії і практики : зб. наук. пр. К. : Вид-во НПУ ім. М. П. Драгоманова, 2013. Вип. 22. С. 29-33.

13. Науменко Н. В. Підготовка майбутнього вчителя до формування духовного здоров’я молодших школярів : автореф. дис. ... на здоб. наук. ступеня канд. пед. наук: спец. 13.00.04 / Харківський національний педагогічний університет імені Г. С. Сковороди. Харків, 2016. 20 с.

14. Силуянова Н. В. Духовность как способ жизнедеятельности человека // Философские науки. 1990. № 12. С. 100-104.

15. Юзвак Ж. М. Духовність: психологічні аспекти // Українська психологія: сучасний потенціал. К., 1996. Т. 3. С. 376-378. 